\title{
Spermatogenesis in several intra- and interspecific hybrids of the lemur (Lemur)
}

\author{
Charline Ratomponirina, J. Andrianivo* and Y. Rumpler
}

Faculté de Médecine, Institut d'Embryologie, 11 rue Humann, 67085 Strasbourg Cédex, France and

*Faculté de Médecine de Tananarive, Laboratoire d'Histologie, Embryologie et Cytogénétique, Madagascar

\begin{abstract}
Summary. Spermatogenesis of various hybrids of the genus Lemur was studied by testicular biopsy. In hybrids between species whose classification is still much debated, the germinal cells had degenerated after the pachytene stage. This abnormality was variable in intensity depending on the parents mating: L. fulvus $(2 \mathrm{~N}=60)$ subspecies $\times$ L. macaco sometimes resulted in fertile offspring while $L$. fulvus collaris $\times$ L. macaco never did. We believe that the defect in spermatogenesis is mostly caused by differences in meiotic behaviour in the germinal cells. In hybrids between two species for which there is no taxonomic doubt ( $L$. fulvus $\times$ L. rubriventer), the gonads were completely devoid of germ cells.
\end{abstract}

\section{Introduction}

Among the lemurs of Madagascar, numerous groups are still engaged in the process of speciation, a phenomenon which poses many problems in the classification of these animals. Such problems are particularly obvious for the genus Lemur with special reference to Lemur fulvus and Lemur macaco. Certain investigators such as Schwartz (1931) based their nomenclature on anatomical or biogeographical characteristics and considered these two animals belonging to the same species, $L$. macaco. On the other hand, some authors (Buettner-Janusch, Swomley \& Chu, 1966) considered that each karyotype must inevitably correspond to a different species, which would therefore admit the existence of 4 separate species: $L$. macaco $(2 \mathrm{~N}=44), L$. fulvus $(2 \mathrm{~N}=60)$, L. collaris $(2 \mathrm{~N}=52)$ and $L$. albocollaris $(2 \mathrm{~N}=48)$. The fundamental chromosome number of all species of this genus is the same, i.e. $N F=64$, because Robertsonian translocations have played a major role in the chromosomal evolution of lemurs (Rumpler, 1975; Rumpler \& Dutrillaux, 1976). Experiments employing hybridizations (Albignac, Rumpler \& Petter, 1971) have shown that in captivity hybrids between $L$. fulvus, $L$. collaris and $L$. albocollaris are regularly fertile in both sexes, while hybrids between these 3 species and L. macaco are usually sterile. Rumpler (1975) therefore concluded that there exist only 2 species, i.e. $L$. macaco $(2 \mathrm{~N}=44)$ and $L$. fulvus in which there is chromosomal polymorphism to give rise to the different subspecies: L. fulvus fulvus, L. fulvus rufus, L. fulvus albifrons, L. fulvus mayottensis $(2 \mathrm{~N}=60)$, L. fulvus collaris $(2 \mathrm{~N}=52)$ and $L$. fulvus albocollaris $(2 \mathrm{~N}=48)$.

The existence of one fertile hybrid (Hamilton \& Moses, 1979) between L. macaco and L. fulvus (out of 9 specimens studied) indicates that sterility after this type of mating is not invariable. Crossbreeding between $L$. fulvus mayottensis $(2 \mathrm{~N}=60)$ and $L$. rubriventer $(2 \mathrm{~N}=50)$ (the latter has always been classified in a separate species) also gives rise to hybrids but they are regularly sterile (Saint-Pie, 1970). We therefore evaluated the fertility potential of the different types of hybrids by using testicular biopsies to examine spermatogenesis. 


\section{Materials and Methods}

We examined groups of male hybrids raised in the Zoological Park of Tananarive, Madagascar, and the School of Medicine, Strasbourg, France. The male parents of these hybrids were included in the controls. Since lemurs have a seasonal reproductive cycle, we have taken samples corresponding to the respective mating season in each hemisphere: December to February in Strasbourg and April to June in Tananarive.

The observations in the present study are based on 9 control specimens $(3 \mathrm{~L}$. fulvus fulvus, $2 \mathrm{~L}$. fulvus mayottensis, 1 L. fulvus rufus and 3 L. macaco) and 9 hybrids $(2$ hybrids of L. macaco $\times L$. fulvus albifrons; 1 hybrid of $L$. fulvus rufus $\times$ L. fulvus albocollaris; 3 hybrids of L. macaco $\times$ L. fulvus collaris; 3 hybrids of $L$. fulvus mayottensis $\times$ L. rubriventer) as presented in Table 1 . Biopsy specimens were taken at the beginning and the end of the mating season for some animals (Z29 and $\mathrm{Z} 12 ; \mathrm{Z} 26$ and Z9; Z11 and Z27).

Biopsies were performed under general anaesthesia and the tissues were fixed by immersion in Bouin's fixative for $24 \mathrm{~h}$. Samples were then dehydrated and embedded in paraffin wax. Sections ( 5 $\mu \mathrm{m}$ ) were cut, mounted on microscope slides and stained in haematoxylin and eosin. We examined spermatogenesis at the level of the seminiferous tubule by counting 1000 cells per specimen and the 7 cell types described by Leblond \& Clermont (1952a, b) were identified: (1) spermatogonium type A, having a spherical nucleus with finely granulated chromatin; (2) spermatogonium type B with an ovoid nucleus containing thick, wrinkled chromatin clumps; (3) spermatocyte I in the leptotene stage in which the nucleus and cytoplasm have a conspicuous volume while the chromatin appears in filamentous threads; (4) spermatocyte $I$ in the zygotene stage in which the chromosomes form long cords and begin to thicken; (5) spermatocyte I in the pachytene stage, in which the cell has a nucleus reaching its maximum developmental stage and the chromosomes are short and thick; (6) cells in metaphase of the maturation division, characterized by the chromosomes on the equatorial plate; and (7) round and elongated spermatids. The elements of spermiogenesis were grouped in one class. Counts were made at different planes of sections in each biopsy to ensure that the resulting figures would be representative of spermatogenesis in the entire sample.

\section{Analysis of results}

The data are expressed as mean \pm s.e.m. The spermatid percentages in relationship to the spermatogenic cells were analysed after angular transformation using the contrast method with the Scheffé test, thus allowing the percentages to be treated like quantitative variables. The following categories were compared: controls with regard to the different types of hybrids $L$. fulvus $(2 \mathrm{~N}=60)$ $\times$ L. fulvus albocollaris $(2 \mathrm{~N}=48) ;$ L. fulvus $(2 \mathrm{~N}=60) \times$ L. macaco $(2 \mathrm{~N}=44) ;$ L. macaco $(2 \mathrm{~N}=$ $44) \times$ L. fulvus collaris $(2 \mathrm{~N}=52)$. The different categories were then compared between themselves.

The index constituted by the relation of the Sertoli cell number to the corresponding number of spermatogenic cells was first studied by two-way analysis of variance with orthogonal comparisons and then by the contrast method with Scheffé's test.

\section{Results}

In $L$. macaco $(2 \mathrm{~N}=44)$ or different subspecies of $L$. fulvus $(2 \mathrm{~N}=60)$, there was a progressive succession of the various cell stages in moving from the periphery to the lumen of the seminiferous tubule. The percentage of more mature cell types was a prominent feature in the homozygotes; spermatids and spermatozoa represented more than half of the total cell population (Pl. 1, Fig. 1).

In the fertile hybrid $(\mathrm{Z} 12)$ of L. fulvus rufus $(2 \mathrm{~N}=60) \times$ L. fulvus albocollaris $(2 \mathrm{~N}=48)$ the same progression was seen as in the pure controls; the percentage of each cell type was also near 
that of the controls (Pl. 1, Fig. 2). The spermatid percentage was not significantly different from that of the controls.

In hybrids resulting from crosses $L$. macaco and $L$. fulvus albifrons $(2 \mathrm{~N}=60)$, these were major variations between individual hybrids. In Hybrid Z9 only a few cells reached maturity. Although spermatogenesis appeared to have begun normally, after the pachytene stage a great majority of cells were degenerating: nuclei were pycnotic or undergoing chromolytic disaggregation and cell lysis (Pl. 1, Fig. 4). Several spermatids and spermatozoa did survive, but the number of cells counted had to be increased by including more tubules. In Hybrid Mt (Pl. 1, Fig. 3) all cell types were present but the number of mature elements was significantly less than that in control tubules. In this hybrid there appeared to be a similar blockage of development beyond the pachytene stage. The percentage of spermatids in relationship to the line cells of this category of hybrid was significantly less than that of the controls $(P<0.05)$.

In the 3 hybrids resulting from $L$. macaco and $L$. fulvus collaris $(2 \mathrm{~N}=52)$, there was no significant variability between individual hybrids (Table 1) and again the more mature cell stages were fewer in number (Pl. 1, Fig. 5). Meiosis rarely continued beyond the pachytene stage and pycnotic nuclei and cells undergoing lysis were frequently seen. The production of spermatids was significantly less than in the controls $(P<0.01)$ but it was not significantly less than in the previous category of hybrids $(P>0 \cdot 1)$.

For the Sertoli cell/spermatogenic cell index, there was no significant difference between $L$. fulvus $(2 \mathrm{~N}=60) \times L$. macaco and L. macaco $\times$ L. fulvus collaris $(P<0.01)$. The three categories of

Table 1. The numbers of Sertoli and germinal cells counted and the percentage of various cell types in testicular biopsies in lemurs

\begin{tabular}{|c|c|c|c|c|c|c|c|c|c|c|}
\hline & & No. of $\mathrm{c}$ & Is counted & & & & & & & \\
\hline & & & & & & & & & & \\
\hline & studied* & cells & cells & $\mathrm{SpA}$ & $\mathrm{SpB}$ & Lep & Zyg & Pachy & Met & Sptid \\
\hline $\mathrm{Z} 2$ & LFF & 24 & 1405 & $2 \cdot 5$ & 1.8 & $5 \cdot 4$ & $8 \cdot 6$ & $19 \cdot 3$ & $2 \cdot 6$ & $59 \cdot 5$ \\
\hline $\mathrm{Z} 3$ & LFF & 29 & 1194 & $4 \cdot 2$ & 4.5 & $1 \cdot 1$ & $1 \cdot 0$ & $25 \cdot 7$ & 0 & $63 \cdot 1$ \\
\hline $\mathrm{Z} 23$ & LFF & 28 & 1211 & $4 \cdot 5$ & $6 \cdot 2$ & $5 \cdot 2$ & $4 \cdot 1$ & $20 \cdot 6$ & 0 & $59 \cdot 1$ \\
\hline $\mathrm{Z} 25$ & LFR & 30 & 1096 & 1.5 & 1.9 & $8 \cdot 2$ & $3 \cdot 7$ & $20 \cdot 1$ & 0 & $64 \cdot 4$ \\
\hline $\mathrm{Al}$ & LFM & 77 & 1337 & 1.4 & 1.0 & $2 \cdot \overline{6}$ & $3 \cdot 0$ & 18.9 & $0 \cdot 3$ & $72 \cdot 5$ \\
\hline A2 & LFM & 103 & 1086 & $2 \cdot 5$ & $4 \cdot 0$ & 0.7 & $1 \cdot 1$ & $15 \cdot 0$ & 0 & $76 \cdot 5$ \\
\hline $\mathrm{Z} 4$ & LMA & 104 & 1250 & 1.9 & $3 \cdot 4$ & 0.8 & 1.6 & 18.8 & $0 \cdot 2$ & $73 \cdot 0$ \\
\hline $\mathrm{Z} 7$ & LMA & 148 & 1178 & $1 \cdot 2$ & $1 \cdot 2$ & $1 \cdot 1$ & 0.5 & $33 \cdot 1$ & 0 & $62 \cdot 7$ \\
\hline $\mathrm{Z} 20$ & LMA & 256 & 967 & 1.9 & $1 \cdot 3$ & $10 \cdot 4$ & $2 \cdot 4$ & $28 \cdot 5$ & $0 \cdot 2$ & 55 \\
\hline Z29 & $\mathrm{LFR} \times \mathrm{LFA}$ & 81 & 1166 & 1.8 & $2 \cdot 2$ & 1.8 & 0.7 & $13 \cdot 2$ & 0 & $80 \cdot 1$ \\
\hline $\mathrm{Z} 12$ & LFR $\times \mathbf{L F A}$ & 71 & 1174 & 0.5 & 0.8 & $2 \cdot 2$ & 1.7 & $41 \cdot 3$ & 0 & $53 \cdot 1$ \\
\hline $\mathrm{Z} 26$ & LMA $\times$ LFL & 340 & 613 & $12 \cdot 2$ & $11 \cdot 7$ & $22 \cdot 0$ & $7 \cdot 8$ & $41 \cdot 2$ & 0 & $4 \cdot 8$ \\
\hline $\mathrm{Z9}$ & $\mathrm{LMA} \times \mathrm{LFL}$ & 245 & 1002 & $5 \cdot 3$ & $5 \cdot 1$ & $9 \cdot 3$ & $13 \cdot 3$ & $66 \cdot 6$ & 0 & 0 \\
\hline Mt & LMA $\times \mathbf{L F L}$ & 206 & 851 & 3.5 & $4 \cdot 2$ & $6 \cdot 1$ & 6.9 & $39 \cdot 3$ & 0.5 & $39 \cdot 2$ \\
\hline St & $\mathrm{LMA} \times \mathrm{LFC}$ & 204 & 809 & $5 \cdot 9$ & $6 \cdot 3$ & $6 \cdot 6$ & 6.7 & $54 \cdot 3$ & $17 \cdot 4$ & $2 \cdot 4$ \\
\hline $\mathrm{Z} 10$ & $\mathrm{LMA} \times \mathrm{LFC}$ & 205 & 958 & 7.5 & $6 \cdot 2$ & $8 \cdot 3$ & $2 \cdot 8$ & $69 \cdot 7$ & 0.7 & 4.5 \\
\hline Z11 & LMA $\times$ LFC & 295 & 846 & 0.4 & $0 \cdot 8$ & 13.9 & $23 \cdot 8$ & $59 \cdot 1$ & 1.7 & 0 \\
\hline Z27 & LMA $\times$ LFC & 299 & 757 & $4 \cdot 6$ & $4 \cdot 7$ & $13 \cdot 4$ & $6 \cdot 3$ & $60 \cdot 7$ & 8.8 & $1 \cdot 1$ \\
\hline A3 & LRU $\times$ LFM & 100 & 0 & 0 & 0 & 0 & 0 & 0 & 0 & 0 \\
\hline A4 & LRU $\times$ LFM & 100 & 0 & 0 & 0 & 0 & 0 & 0 & 0 & 0 \\
\hline A5 & LRU $\times$ LFM & 100 & 0 & 0 & 0 & 0 & 0 & 0 & 0 & 0 \\
\hline
\end{tabular}

* LFF $=$ Lemur fulvus fulvus; LFR $=$ Lemur fulvus rufus; LMA $=$ Lemur macaco $;$ LFA $=$ Lemur fulvus albocollaris; $\mathrm{LFL}=$ Lemur fulvus albifrons; $\mathrm{LFC}=$ Lemur fulvus collaris; $\mathrm{LFM}=$ Lemur fulvus mayottensis; $\mathrm{LRU}=$ Lemur rubriventer.

$+\mathrm{SpA}=$ spermatogonia $\mathrm{A} ; \mathrm{SpB}=$ spermatogonia $\mathrm{B} ;$ Lep = spermatocyte $\mathrm{I}$, leptotene $; \mathrm{Zyg}=$ spermatocyte I, zygotene; Pachy = spermatocyte I, pachytene; Met = metaphase II; Sptid = Spermatid. 
controls, $L$. fulvus $(2 \mathrm{~N}=60) \times$ L. albocollaris, and the above group differed overall $\left(\mathrm{F}_{14}^{2}=4 \cdot 54, P\right.$ $<0.05$ ), but Scheffé's test indicated a difference only between the controls and $L$. macaco $\times L$. fulvus collaris.

The cause of sterility in hybrids of $L$. rubriventer $\times$ L. fulvus fulvus is evident. The seminiferous tubules of those hybrids were completely depleted of germ cells and contained only Sertoli cells (PI. 1, Fig. 6). The pathology in this case appears analogous to that known as the 'Sertoli cell only syndrome' observed in man (del Castillo, Trabucco \& de la Balze, 1947).

\section{Discussion}

The histology of testicular biopsies of the hybrid between $L$. fulvus albocollaris $(2 \mathrm{~N}=48)$ and $L$. fulvus rufus $(2 \mathrm{~N}=60)$ was very similar to that of the controls and this type of hybrid is fertile in the present conditions of captivity.

Crosses between $L$. macaco $(2 \mathrm{~N}=44)$ and the $L$. fulvus $(2 \mathrm{~N}=60)$ subspecies yield offspring which are usually sterile although Hamilton \& Moses (1979) reported one case in which such a hybrid successfully mated three times. The histological variation in spermatogenesis between these hybrids, indicates why certain specimens may have a less serious disruption of spermatogenesis and may even be fertile. Furthermore, as in men with sterility problems, it is possible that a male with a relatively low degree of fertility can have progeny if he mates with a particularly fecund female.

Crosses between $L$. macaco $(2 \mathrm{~N}=44)$ and $L$. fulvus collaris $(2 \mathrm{~N}=52)$ produce sterile offspring. Spermatogenesis is strongly disrupted and, in the three hybrids studied, the majority of cells degenerated shortly after the pachytene stage; spermatids and spermatozoa were therefore rare in the seminiferous tubules.

The seminiferous tubules of hybrids between $L$. fulvus mayottensis $\times L$. rubriventer show a complete absence of germinal cells. However, it is not possible to tell from these histological specimens whether the germinal cells degenerated in the tubules post-natally (Lutz-Ostertag, 1965) or during embryonic development.

The 5 varieties of lemurs studied differ among themselves at the chromosomal level by displaying Robertsonian translocations (Rumpler, 1975; Rumpler \& Dutrillaux, 1976). A relation could exist between the number of chromosomal rearrangements which have occurred and the disruption of spermatogenesis, especially as the different subspecies of $L$. fulvus with $2 \mathrm{~N}=60$ regularly produce fertile hybrids (Rumpler, 1975). Other factors, however such as the genome of the individual hybrid or even the gene component of the translocated chromosomes (Cattanach \& Moseley, 1973; White, Crandall, Raveché \& Tjio, 1978) may contribute to the condition. It is surprising that the existence of 6 centric fusions between $L$. fulvus rufus $(2 \mathrm{~N}=60)$ and $L$. fulvus albocollaris does not perturb spermatogenesis, as has been reported for other species, and the phenomenon of increased chromosomal rearrangements existing between subspecies of $L$. fulvus $(2 \mathrm{~N}=60)$ and $L$. macaco cannot alone explain spermatogenic malfunction in those hybrids.

The chromosomal pairing in hybrids between $L$. fulvus $(2 \mathrm{~N}=60)$ subspecies and the different species or subspecies of which the karyotype was derived from that of $L$. fulvus $(2 \mathrm{~N}=60)$ by centric fusions, includes trivalents. In spite of the relatively high proportion of trivalents the spermatogenesis of these hybrids is nearly normal ( $L$. fulvus rufus $\times$ L. fulvus albocollaris) or disturbed, but to a varied degree in some specimens ( $L$. fulvus albifrons $\times$ L. macaco) such that at least some fertile hybrids can occur (Hamilton \& Moses, 1979).

However, spermatogenesis is strongly disrupted and regularly results in sterility of the hybrids between the different species or subspecies of which the karyotype is derived from that of $L$. fulvus $(2 \mathrm{~N}=60)$, i.e. L. fulvus collaris $\times$ L. macaco. The Robertsonian translocations which occurred in the different karyotypes did not concern the same chromosomes, and the chromosomes form elongated chains during meiotic pairing in these hybrids (Dutrillaux \& Rumpler, 1977) as has been reported by others (Gropp, Tettenborn \& Von Lehmann, 1970; Forejt, 1979). Therefore, for 

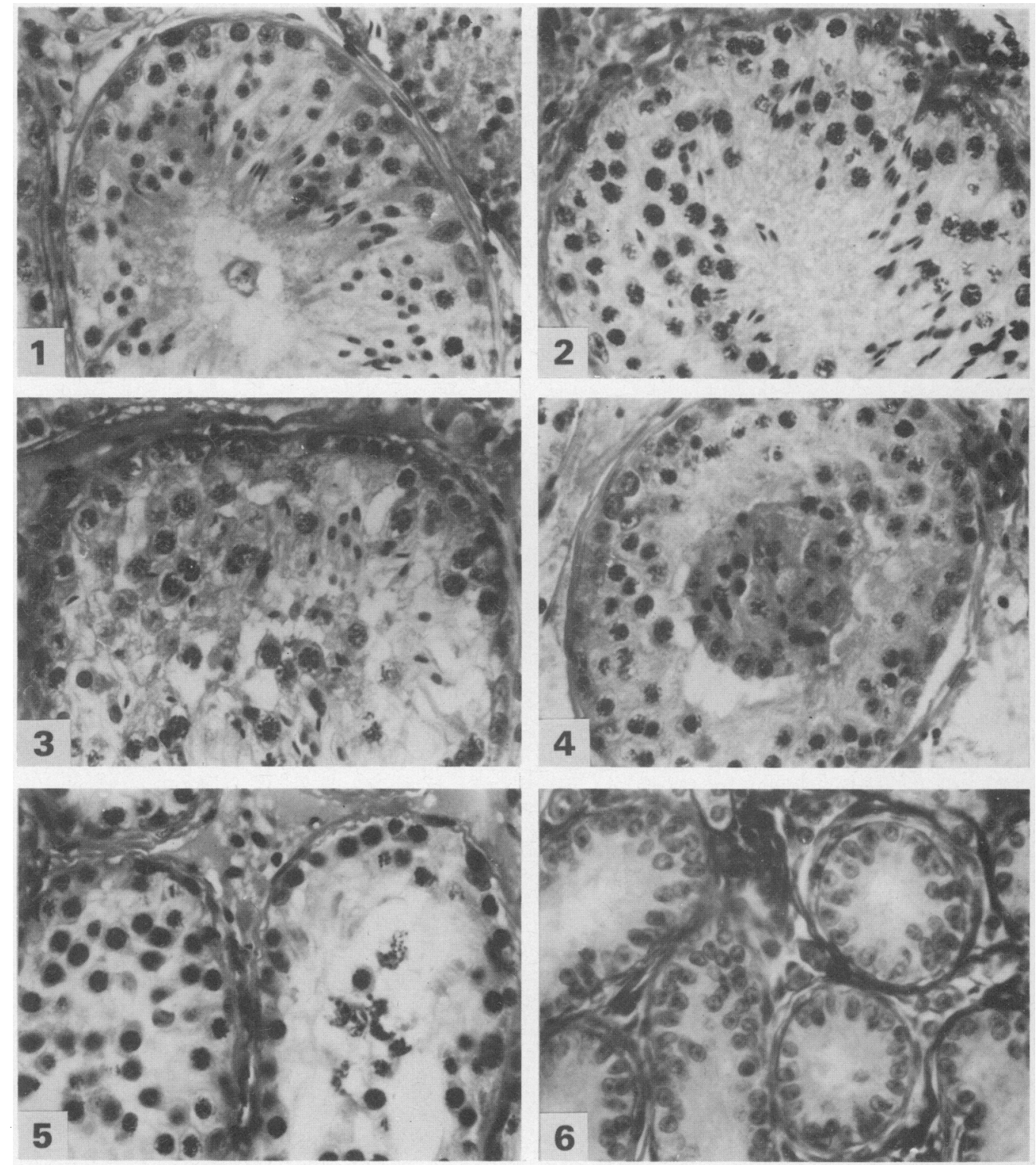

Testicular sections of Lemur fulvus fulvus (Fig. 1), L. fulvus rufus $\times$ L.fulvus albocollaris (Fig. 2), L. fulvus albifrons $\times$ L. macaco (Figs 3 and 4), L. fulvus collaris $\times$ L. macaco (Fig. 5) and L. fulvus mayottensis $\times$ L. rubriventer (Fig. 6). Spermatogenesis has progressed further in Fig. 3 than in Fig. 4 despite the fact that both hybrids are of similar type. There is a total absence of germinal cells in Fig. $6 . \mathrm{H} \& \mathrm{E} ; \times 40$. 
hybrids between two discrete species for which there are clear taxonomic relationships, e.g. $L$. fulvus and L. rubriventer, spermatogenesis is null. When the germinal cells are completely lacking, the resulting sterility is not caused by a defect in meiosis due to an accumulation of centric fusions, but rather to genetic factors.

We thank Professor Roos and Mr Montagnon for help with the statistics. The work was supported by Fondation pour le Recherche Médicale Française and INSERM, contract No. 008 ATP 78-79-110.

\section{References}

Albignac, R., Rumpler, Y. \& Petter, J.J. (1971) L'hybridation des Lémuriens de Madagascar. Mammalia 35, 358-368.

Buettner-Janusch, J., Swomley, B.A. \& Chu, E.H.Y. (1966) Le nombre chromosomique de certains Lémuriens de Madagascar et les problèmes de différenciation des espèces. Cah.ORSTOM-Biol. 2, 3 7.

Cattanach, B.M. \& Moseley, H. (1973) Non disjunction and reduced fertility caused by the Tobacco mouse metacentric chromosomes. Cytogenet. Cell Genet. 12 , 264-287.

del Castillo, E., Trabucco, A. \& de la Balze, F. (1947) Syndrome produced by absence of germinal epithelium without impairment of the Sertoli cells. J. clin. Endocr. Metab. 7, 493-500.

Dutrillaux, B. \& Rumpler, Y. (1977) Meiosis in intraspecific and interspecific hybrids in the genus Lemur. Cytogenet. Cell Genet. 18, 197-211.

Forejt, J. (1979) Meiotic studies of translocations causing male sterility in the mouse. II. Double heterozygotes for Robertsonian translocations. Cytogenet. Cell Genet. 23, 163-170.

Gropp, A., Tettenborn, U. \& Von Lehmann, E. (1970) Chromosomen variation vom Robertsonschen Typus bei der Tabak Maus M. poschiavinus und ihren Hybriden mit der Laboratoriums Maus. Cytogenetics 9, 923.

Hamilton, A.E. \& Moses, M.J. (1979) Fertility in Lemur macaco $\times$ Lemur fulvus hybrids. Am. J. Phys. Anthrop. 50, 413-414.

Leblond, C.P. \& Clermont, Y. (1952a) Definition of the stages of the cycle of the seminiferous epithelium of the rat. Ann. N. Y. Acad. Sci. 55, 548-584.
Leblond, C.P. \& Clermont, Y. (1952b) Spermiogenesis of rat, mouse, hamster and guinea pig as revealed by the periodic acid-fuchsin sulfurous acid technique. $\mathrm{Am}$. J. Anat. 90, 167-216.

Lutz-Ostertag, Y. (1965) Le croisement canard Khaki Camphell (Anas plathyrhynchos L) $\times$ Cane Barbarie (Cairina moschata L). 1) Etude de l'appareil génital des embryons et des adultes. 2) Etude de l'activité des gonades. Archs. Anat. Histol. Embryol. 48, 301-327.

Rumpler, Y. (1975) The significance of chromosomal studies in the systematics of the malagasy Lemurs. In Lemur Biology, pp. 25-40. Eds I. Tattersal \& R. Sussman. Plenum Press, New York.

Rumpler, Y. \& Dutrillaux, B. (1976) Chromosomal evolution in Malagasy Lemurs. I. Chromosomes banding studies in the genuses Lemur and Microcebus. Cytogenet. Cell Genet. 17, 268-281.

Saint-Pie, J. (1970) Birth and rearing of a Brown-lemur $\times$ Red bellied Lemur fulvus $\times$ L. rubriventer and breeding of Grey gentle lemur Hapalemur griseus at Asson Zoo. Int. Zoo Yb. 10, 71-72.

Schwartz, E. (1931) A revision of the genera and species of Madagascar Lemuridae. Proc. Zool. Soc., Lond. 399-428.

White, B.J., Crandall, C., Raveché, E.S. \& Tjio, J.H. (1978) Laboratory mice carrying three pairs of Robertsonian translocations: establishment of a strain and analysis of meiotic segregation. Cytogenet. Cell Genet. 21, 113-138.

Received 13 April 1982 